\title{
Pengolahan Limbah Cair Industri Pakan Ternak dengan Kombinasi Proses Aerasi dan Biologi Aerob
}

\section{Wastewater Treatment of Animal Feed Industry Using Combination of Aeration and Biological Aerobic Process}

\author{
KETUT SUMADA, NOVIKA CAHYA CHAERANI, MELANDY DWI PRIAMBODHO, DAN \\ ERWAN ADI SAPUTRO* \\ Program Studi Teknik Kimia, Fakultas Teknik, Universitas Pembangunan Nasional "Veteran" Jawa Timur \\ J. Raya Rungkut Madya, Surabaya 60294 \\ Email: erwanadi.tk@upnjatim.ac.id
}

\begin{abstract}
Wastewater is unclean and contains various substances that can risk the lives of humans and animals. This waste usually comes from the results of human actions (including industrialization). Industry must apply the principle of waste control in a careful and integrated system. Aeration is one of the most widely used techniques for improving the physical and chemical characteristics of wastewater. The aerobic microbiological wastewater treatment process utilizes aerobic microbial activity in aerobic conditions to decompose organic matter in wastewater into stable inorganic substances that don't provide pollution impacts on the environment. This study determines the best time for the aeration process to reduce Chemical Oxygen Demand (COD) or Biological Oxygen Demand (BOD) of animal feed wastewater and the volume ratio of waste, that is, the number of microorganisms to reduce $C O D$ and $B O D$ of animal feed wastewater. The study results show that the longer the aeration contact time, the more significant the decrease in $C O D$ and $B O D$ values. In addition, the greater the addition of microbial concentration, the more effective the reduction in $C O D$ and $B O D$ values. Furthermore, the aeration process time with microbial concentration, which will produce the best $C O D$ and $B O D$ reduction, is 6 hours. Unfortunately, the $C O D$ and $B O D$ values still do not meet the wastewater quality standards in the aeration process. Still, with microbial concentrations, $C O D$ and $B O D$ values reduction targets will be obtained in the aerobic biological process, following the wastewater quality standards. Finally, wastewater processing from the animal feed industry with a combination of aeration and aerobic biology can meet quality standards.
\end{abstract}

Keywords: aerobic, anaerobic, animal feed, $B O D, C O D$, wastewater

\begin{abstract}
ABSTRAK
Air limbah merupakan air yang tidak bersih atau yang mempunyai kandungan berbagai zat yang berbahaya bagi kelangsungan hidup manusia, hewan, dan tumbuhan. Biasanya limbah dihasilkan dari kegiatan manusia (termasuk industrialisasi) sehingga sudah sepatutnya perindustrian mengelola hasil buangannya sesuai kaidah pengolahan limbah secara terpadu, efisien, dan efektif. Aerasi merupakan salah satu teknik yang paling banyak digunakan dalam perbaikan karakteristik fisik dan kimiawi air limbah. Terdapat berbagai proses pengolahan limbah di mana salah satunya dengan memanfaatkan aktivitas mikroba aerob untuk menguraikan zat organik dalam kondisi aerob menjadi zat anorganik yang stabil yang tidak mencemari lingkungan. Tujuan dari penelitian ini adalah mengetahui waktu terbaik proses aerasi terhadap penurunan Chemical Oxygen Demand (COD) atau Biological Oxygen Demand (BOD) limbah cair pakan ternak dan mengetahui rasio volume limbah, yaitu jumlah mikroorganisme terhadap penurunan COD dan BOD limbah cair pakan ternak. Kesimpulan hasil kajian yaitu waktu pengontakan aerasi semakin lama dan penambahan konsentrasi mikroba berpengaruh pada penurunan nilai COD dan BOD dengan penurunan terbaik didapatkan pada waktu 6 jam. Nilai COD dan BOD proses biologi aerob dengan penambahan konsentrasi mikroba pada proses aerasi dan kombinasi aerasi dan biologi aerob telah memenuhi standar baku mutu limbah tetapi pada proses aerasi belum.
\end{abstract}

Kata kunci: aerob, anaerob, BOD, COD, limbah cair, pakan ternak

\section{PENDAHULUAN}

\subsection{Latar Belakang}

Perkembangan perindustrian yang cepat di beberapa tahun terakhir dapat mempengaruhi segala aspek kehidupan baik untuk kehidupan manusia maupun kehidupan lingkungan. Industri tersebut akan mengeluarkan bermacam-macam limbah seperti limbah padat, cair, dan gas. Limbah tersebut dapat mencemari lingkungan. Sampai saat ini limbah masih menjadi masalah serius yang perlu ditangani keberadaannya.

Industri yang dapat mencemari lingkungan salah satunya adalah industri pakan ternak. 
Limbah dari industri pakan ternak berupa limbah cair yang berasal dari proses pengolahan dan pencucian alat produksi. Dari proses pengolahan dan pencucian alat produksi, limbah cair yang didapat langsung dibuang ke sungai. Hal itu sangat mengganggu masyarakat dan lingkungan sekitar. Sesuai dengan Undang-Undang Republik Indonesia Nomor 32 Tahun 2009 tentang Perlindungan dan Pengelolaan Lingkungan Hidup dan standar baku mutu untuk limbah cair industri sesuai dengan Keputusan Menteri Negara Lingkungan Hidup Nomor KEP51/MENLH/10/1995 dengan parameter COD dan BOD, yaitu nilai COD yakni $100-300 \mathrm{mg} / \mathrm{L}$ dan nilai $B O D$ yakni $50-150 \mathrm{mg} / \mathrm{L}^{(1,2)}$.

Namun dalam uji analisis awal COD, BOD, serta $\mathrm{pH}$ dari limbah cair industri pakan ternak ini diperoleh nilai kadar COD sebesar $750 \mathrm{mg} / \mathrm{L}$ dan untuk nilai BOD diperoleh sebesar $500 \mathrm{mg} / \mathrm{L}$. Berdasarkan hasil uji analisis COD dan BOD dari limbah cair pakan ternak belum memenuhi nilai standar baku mutu limbah cair sesuai dengan peraturan yang telah dikeluarkan.

Oleh karena itu, limbah tersebut perlu dilakukan suatu pengolahan agar dapat mengurangi pencemaran lingkungan yang ada di sekitar industri. Maka dilakukanlah penelitian ini yang membahas tentang pengolahan limbah cair industri pakan ternak dengan cara kombinasi proses aerasi dan biologi aerob agar memenuhi standar baku mutu yang baik saat pembuangan limbah ke aliran buangan/sungai. Pada penelitian ini, metode aerob digunakan karena metode ini adalah salah satu metode terbaik dalam mengolah limbah buangan domestik dan non domestik baik dari industrialisasi maupun dari limbah rumah tangga ${ }^{(3)}$.

Dalam penelitian ini rasio jumlah mikroba terhadap volume limbah cair akan mempengaruhi hasil dalam pengolahan limbah cair. Adapun hasil yang didapatkan dengan menggabungkan kedua proses tersebut diharapkan dapat menurunkan nilai COD dan BOD yang ada dalam limbah tersebut menjadi lebih baik.

Pengolahan air limbah secara biologi biasanya menggunakan mikroorganisme yang dapat mengubah senyawa-senyawa kimia dalam air limbah yang berbahaya menjadi tidak berbahaya. Parameter yang biasa digunakan dalam pengolahan limbah cair dengan proses biologi adalah BOD dan COD.

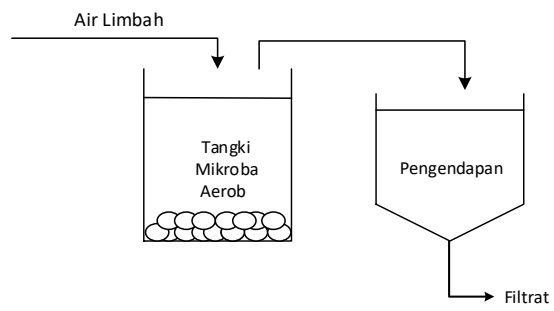

Gambar 1. Proses biologi aerob
Salah satu proses biologi yang sering digunakan adalah proses lumpur aktif dalam pengolahan air limbah secara biologi aerob. Di dalamnya terlibat reaksi-reaksi metabolik mikroba yang berfungsi dalam mengonversi air limbah. Tujuan dari proses ini di antaranya adalah menghilangkan BOD dan mendapatkan kualitas effluent yang dipersyaratkan. Substansi yang ada dikonversi oleh mikroorganisme dalam lumpur aktif sehingga zat organik dalam limbah bisa dijadikan sebagai sumber nutrisi serta untuk pertumbuhan sel baru(4). Mekanisme reaksi dalam proses ini adalah:

Zat organik $+\mathrm{MO} \longrightarrow \mathrm{CO}_{2}+\mathrm{H}_{2} \mathrm{O}+\mathrm{NH}_{3}+$ sel - sel baru ${ }^{(3)}$

Peningkatan konsentrasi oksigen yang terkandung dalam air limbah dilakukan dengan cara aerasi sehingga proses oksidasi biologi oleh mikroba dapat berjalan dengan optimal. Penambahan oksigen ini akan membantu pertumbuhan pada mikroba yang akan berguna untuk menguraikan zat-zat organik yang ada pada limbah cair tersebut. Sehingga zat-zat organik terurai menjadi sederhana. Dalam proses ini, udara atau oksigen murni dimasukkan ke dalam air limbah melalui benda porous atau nozzle.

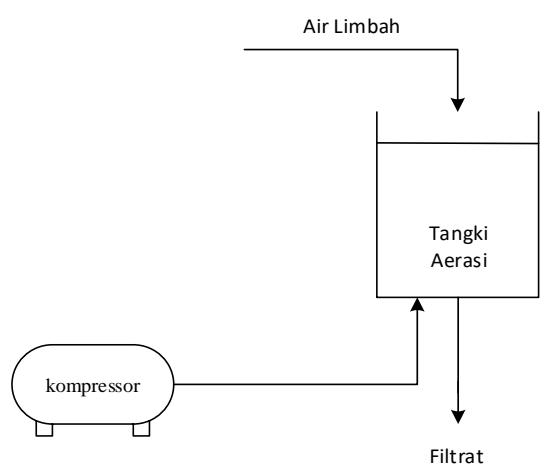

Gambar 2. Proses aerasi

Bakteri yang berperan dalam penurunan organik karbon adalah bakteri heterotropik, di mana oksidasi senyawa organik menjadi sumber energi dan organik karbon sebagai sumber karbon. Untuk itu, sebagai ukuran atau satuan yang menyatakan konsentrasi organik karbon digunakan parameter BOD atau COD dipakai yang selanjutnya disebut substrat ${ }^{(3)}$. Proses lumpur aktif bergantung pada keberadaan sejumlah mikroorganisme dalam bentuk suspensi flog, yang kontak dengan senyawa organik dalam air limbah melalui pengadukan. Agitasi mekanis dengan turbin atau udara yang bergerak dapat digunakan untuk mencapai kondisi aerasi.

Proses lumpur aktif terdiri dari dua tangki. Pertama adalah tangki aerasi sebagai tempat berlangsungnya degradasi dan konversi biokimia senyawa organik oleh mikroba yang terjadi di lingkungan yang sangat teroksigenasi. Air limbah 
bersama lumpur aktif masuk ke dalam tangki aerasi dengan kondisi suplai oksigen diberikan secara terus menerus. Proses penguraian biologis komponen organik dalam air limbah oleh bakteri dalam lumpur menghasilkan gas $\mathrm{CO}_{2}$ dan sel-sel baru juga terjadi di dalam di tangki aerasi ini. Dengan sel tambahan yang dibuatnya, jumlah bakteri di tangki aerasi akan bertambah. Tangki kedua dalam proses lumpur aktif adalah tangki biosolid di mana lumpur aktif dipisahkan dari cairan. Berikut ini merupakan mekanisme reaksi oksidasi sel yang terjadi dalam air limbah:

$\mathrm{CHONS}+\mathrm{O}_{2} \longrightarrow \mathrm{CO}_{2}+\mathrm{NH}_{3}+\mathrm{C}_{5} \mathrm{H}_{7} \mathrm{NO}_{2} \ldots .$.

Sedangkan reaksi oleh biomassa berupa Sintesis/ Respirasi adalah sebagai berikut:

$\mathrm{C}_{5} \mathrm{H}_{7} \mathrm{NO}_{2}+5 \mathrm{O}_{2} \longrightarrow 5 \mathrm{CO}_{2}+\mathrm{H}_{2} \mathrm{O}+\mathrm{NH}_{3}+$ Energi (3)

Proses aerasi dan biologi aerob dipengaruhi oleh beberapa faktor antara lain waktu kontak, debit oksigen/udara, jenis mikroba, jumlah mikroba, dan $\mathrm{pH}$.

\subsection{Tujuan Penelitian}

Penelitian ini bertujuan untuk mempelajari dan mengetahui waktu terbaik proses aerasi terhadap penurunan COD dan BOD limbah cair pakan ternak serta mengetahui rasio volume limbah, yaitu jumlah mikroorganisme terhadap penurunan COD dan BOD limbah cair pakan ternak. Hasil penelitian diharapkan dapat memberikan informasi/referensi standar baku mutu limbah industri yang baik dalam proses pengolahan limbah industri.

\section{BAHAN DAN METODE}

\subsection{Bahan}

Dalam penelitian ini bahan utama yang dipergunakan adalah limbah cair dari salah satu industri pakan ternak, sedangkan mikroba yang dipergunakan berasal dari lumpur aktif yang diperoleh dari PT. SIER Surabaya yang berdasarkan analisis mengandung berbagai jenis mikroba seperti: Rotifer, Melicerta, Pseudomonas, Vorticella, Zooglea, Flavobacterium, Nocardia, Achromobacter, Bdellovibrio, Mycobacterium, Nitrobacter, dan Nitrosomonas.

\subsection{Metode}

Penelitian diawali dengan melakukan analisis kadar COD, BOD, dan $\mathrm{pH}$ limbah cair industri pakan ternak sebelum dilakukan proses pengolahan. Dalam penelitian ini limbah cair industri pakan ternak dilakukan pengolahan dengan 2 (dua) tahap yaitu pertama dilakukan pengolahan dengan proses aerasi dalam suatu tangki aerasi dan hasil proses aerasi dilakukan pengolahan kedua yaitu pengolahan dengan proses biologi aerob. Limbah cair dimasukkan ke dalam tangki aerasi sebanyak $4 \mathrm{~L}$ dan diaerasi selama waktu yang telah ditentukan dengan bantuan oksigen dari alat kompresor dengan debit $4 \mathrm{~L} /$ menit. Kemudian limbah cair dialirkan ke dalam tangki biologi aerob di mana di dalamnya terdapat mikroorganisme (lumpur aktif) dengan jumlah yang sudah ditentukan dan diproses dengan bantuan oksigen dari alat kompresor selama selang waktu yang ditentukan. Limbah cair setelah mengalami proses biologi aerob, dialirkan ke tangki penampung hasil pengolahan dan dilakukan proses pengendapan. Filtrat limbah cair diambil dan dianalisis kadar COD, BOD, dan $\mathrm{pH}$ sementara untuk endapan yang berupa mikroorganisme (padat) bisa dipergunakan kembali (recycle) atau diolah menjadi pupuk padat organik. Gambar peralatan penelitian seperti tercantum dalam Gambar 3.

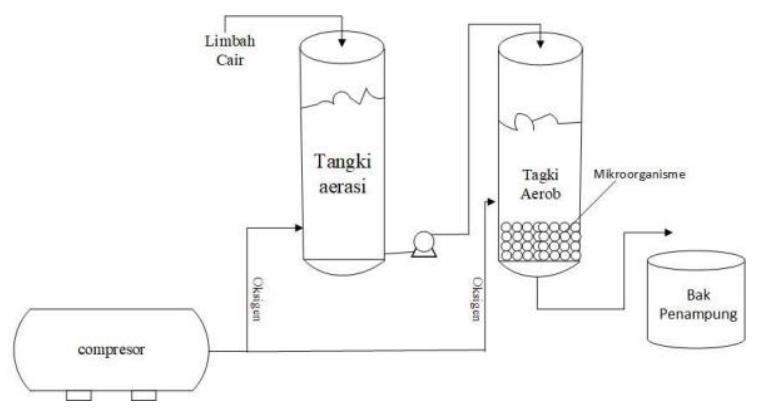

Gambar 3. Rangkaian alat

Metode analisis untuk COD adalah mengacu kepada metode titrasi, untuk analisis $\mathrm{BO}$ mengacu kepada Metode Winkler, dan pengukuran derajat keasaman $(\mathrm{pH})$ dengan menggunakan peralatan pH digital.

\section{HASIL DAN PEMBAHASAN}

\subsection{Analisis Awal Limbah}

Tabel 1. Hasil analisis awal limbah cair industri pakan ternak

\begin{tabular}{cc}
\hline Parameter & Hasil Analisis \\
\hline COD & $1035,97 \mathrm{mg} / \mathrm{L}$ \\
\hline $\mathrm{BOD}$ & $937,63 \mathrm{mg} / \mathrm{L}$ \\
\hline $\mathrm{pH}$ & 7,58
\end{tabular}


3.2 Tabel Hasil Analisis

Tabel 2. Hasil analisis COD, BOD, dan $\mathrm{pH}$

\begin{tabular}{|c|c|c|c|c|c|c|}
\hline No. & $\begin{array}{c}\text { Konsentrasi } \\
\text { Mikroorganisme (mg/L) }\end{array}$ & $\begin{array}{l}\text { Waktu } \\
\text { (Jam) }\end{array}$ & $\begin{array}{l}\text { COD } \\
(\mathrm{mg} / \mathrm{L})\end{array}$ & $\begin{array}{l}\text { BOD } \\
(\mathrm{mg} / \mathrm{L})\end{array}$ & $\begin{array}{c}\text { Persen } \\
\text { Penurunan COD } \\
\text { (\%) }\end{array}$ & $\begin{array}{c}\text { Persen } \\
\text { Penurunan BOD } \\
(\%)\end{array}$ \\
\hline \multirow{5}{*}{1} & \multirow{5}{*}{0} & 6 & 223,46 & 101,4 & 78,42 & 89,18 \\
\hline & & 5 & 372,7 & 107,72 & 64,02 & 88,51 \\
\hline & & 4 & 586,99 & 287,14 & 43,33 & 69,37 \\
\hline & & 3 & 513,01 & 192,54 & 50,48 & 88,93 \\
\hline & & 2 & 944,13 & 437,02 & 8,86 & 53,39 \\
\hline \multirow{5}{*}{2} & \multirow{5}{*}{$1.242,9$} & 6 & 189,03 & 69,76 & 15,40 & 31,20 \\
\hline & & 5 & 278,32 & 79,45 & 25,32 & 26,24 \\
\hline & & 4 & 354,85 & 124,61 & 39,54 & 56,60 \\
\hline & & 3 & 492,6 & 186,83 & 3,97 & 2,96 \\
\hline & & 2 & 854,85 & 390,93 & 9,45 & 10,54 \\
\hline \multirow{5}{*}{3} & \multirow{5}{*}{$1.422,7$} & 6 & 178,83 & 47,02 & 19,97 & 53,62 \\
\hline & & 5 & 210,43 & 50,64 & 43,53 & 52,98 \\
\hline & & 4 & 354,85 & 97,63 & 20,42 & 65,99 \\
\hline & & 3 & 467,1 & 183,28 & 8,94 & 4,80 \\
\hline & & 2 & 693,71 & 278,13 & 26,52 & 36,35 \\
\hline \multirow{5}{*}{4.} & \multirow{5}{*}{$2.195,6$} & 6 & 158,42 & 49,67 & 29,10 & 51,01 \\
\hline & & 5 & 251,63 & 102,36 & 32,48 & 4,97 \\
\hline & & 4 & 236,2 & 96,34 & 59,76 & 66,44 \\
\hline & & 3 & 237,5 & 106,32 & 53,70 & 44,78 \\
\hline & & 2 & 541,07 & 171,91 & 29,10 & 60,66 \\
\hline \multirow{5}{*}{5.} & \multirow{5}{*}{$2.691,5$} & 6 & 143,11 & 45,3 & 35,95 & 55,32 \\
\hline & & 5 & 145,66 & 74,79 & 60,91 & 30,56 \\
\hline & & 4 & 160,97 & 89,31 & 72,57 & 68,89 \\
\hline & & 3 & 171,68 & 104,16 & 66,53 & 45,90 \\
\hline & & 2 & 393,11 & 102,31 & 58,36 & 76,58 \\
\hline \multirow{5}{*}{6.} & \multirow{5}{*}{$2.949,4$} & 6 & 65,66 & 30,26 & 70,61 & 70,15 \\
\hline & & 5 & 107,4 & 33,99 & 71,18 & 68,44 \\
\hline & & 4 & 109,95 & 38,23 & 81,26 & 86,68 \\
\hline & & 3 & 121,87 & 88,69 & 87,09 & 53,93 \\
\hline & & 2 & 357,26 & 101,5 & 62,15 & 76,77 \\
\hline
\end{tabular}

\subsection{Pengaruh Waktu Aerasi Terhadap Penurunan COD dan BOD}

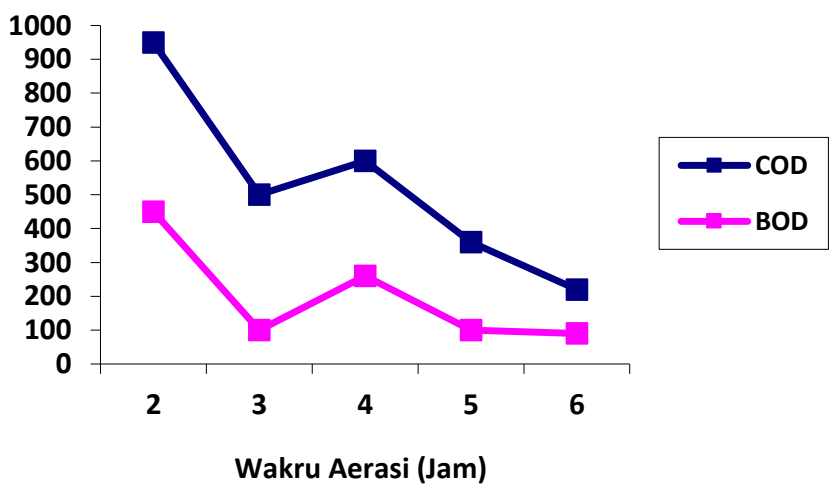

Gambar 4. Penurunan COD dan BOD terhadap waktu aerasi 


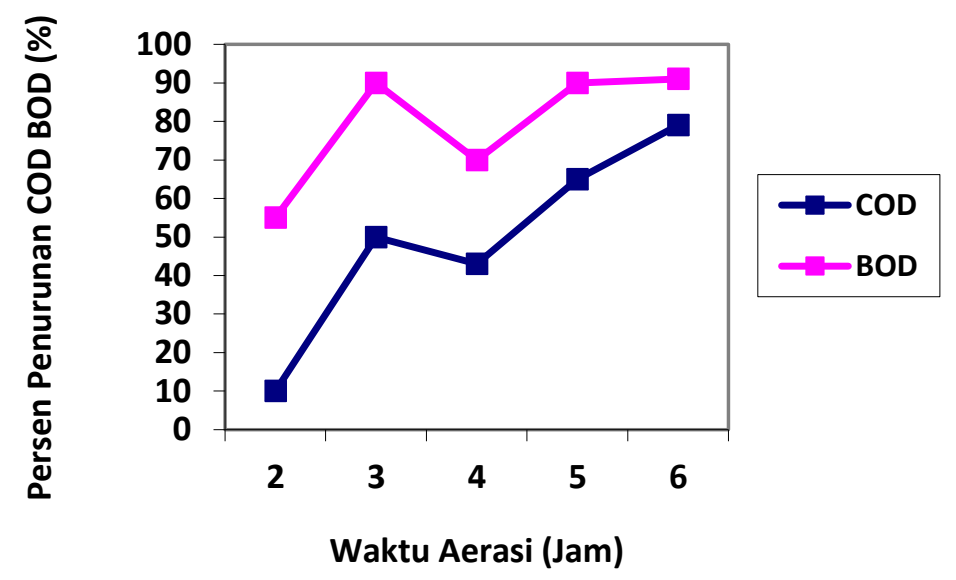

Gambar 5. Persentase penurunan COD dan BOD

Gambar 4. menunjukkan hasil COD dan BOD dari air limbah yang telah dilakukan pengolahan dengan proses aerasi dengan waktu yakni 2, 3, 4, 5, dan 6 jam. Turunnya nilai COD dan BOD dipengaruhi oleh banyaknya suplai oksigen yang diberikan sehingga dengan tercukupinya suplai oksigen terjadi proses oksidasi yang dapat membantu menguraikan bahan-bahan organik pada air limbah ${ }^{(9)}$.

Dengan semakin lama waktu pengontakan aerasi akan menimbulkan waktu kontak antara oksigen dan air limbah semakin besar pula. Hal ini menyebabkan penurunan nilai $C O D$ dan $B O D$ semakin besar pula.

Pada proses aerasi didapatkan waktu terbaik yaitu 6 jam. Dengan nilai COD awal sebesar
$1.035,97 \mathrm{mg} / \mathrm{L}$ dan BOD awal sebesar 937,63 $\mathrm{mg} / \mathrm{L}$. Nilai COD akhir sebesar $223,46 \mathrm{mg} / \mathrm{L}$ dengan persentase penurunan $78,42 \%$ dan BOD akhir sebesar $101,4 \mathrm{mg} / \mathrm{L}$ dengan persentase penurunan $89,18 \%$. Hasil penurunan yang dihasilkan pada penelitian ini sejalan dengan penelitian lain yang menemukan bahwa aerasi berpengaruh tinggi dalam menyisihkan BOD yaitu berkisar antara $69-89 \%{ }^{(10)}$. Hal ini juga didukung dengan penelitian-penelitian lainnya yang menyatakan bahwa semakin lama waktu aerasi yang diberikan pada air limbah, maka nilai BOD dan COD dari air limbah akan semakin kecil dikarenakan konsentrasi limbah yang terlarut dalam air menurun ${ }^{(6,7,9)}$.

\subsection{Pengaruh Konsentrasi Mikroba Terhadap Penurunan COD}

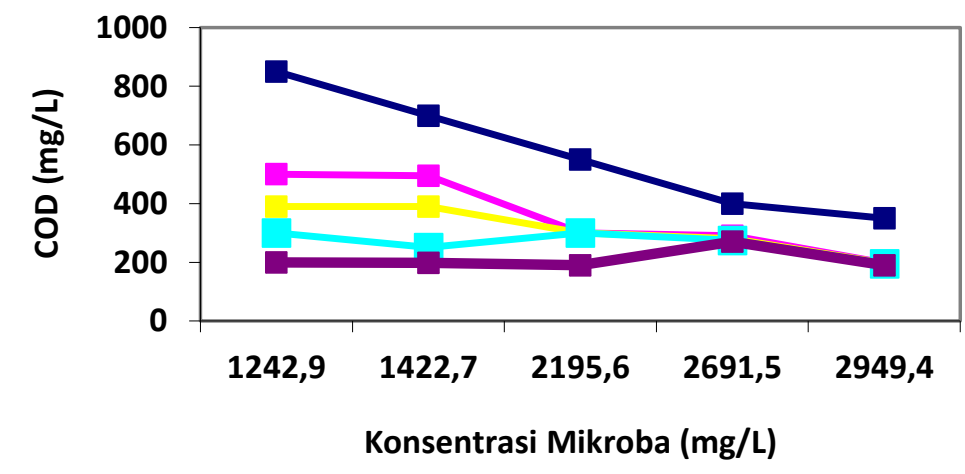

$-2 \mathrm{Jam}-2 \mathrm{Jam}-4 \mathrm{Jam}-5 \mathrm{Jam}=6 \mathrm{Jam}$

Gambar 6. Hubungan konsentrasi mikroba terhadap penurunan COD 


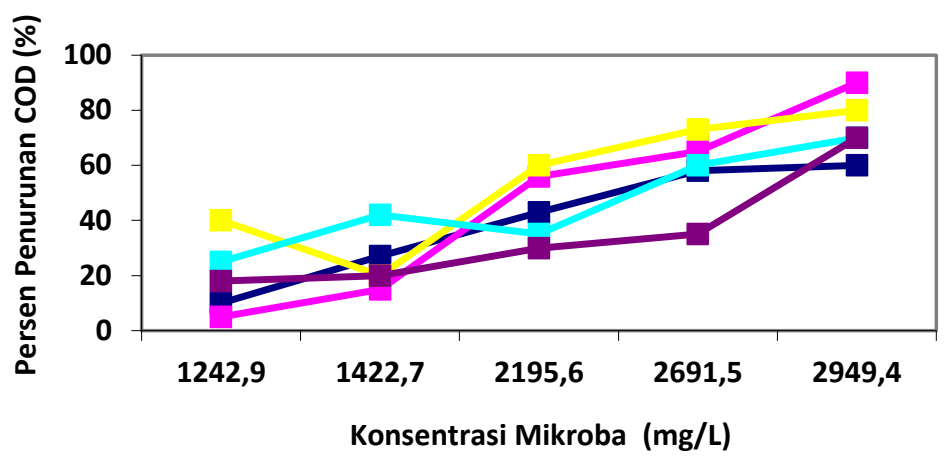

-2 Jam $-3 \mathrm{Jam}-4 \mathrm{Jam}-5 \mathrm{Jam}=6 \mathrm{Jam}$

Gambar 7. Persentase penurunan COD (\%)

Gambar 6. menunjukkan penurunan hasil COD dengan penambahan konsentrasi mikroba pada proses aerasi. Dengan semakin besar waktu pengontakan aerasi serta dengan penambahan konsentrasi mikroba maka akan semakin besar proses pendegradasian bahan organik yang ada pada air limbah. Hal ini menyebabkan penurunan nilai COD dan BOD menjadi semakin besar. Pada proses ini didapatkan waktu terbaik yaitu 6 jam. Dengan nilai COD awal sebesar $223,46 \mathrm{mg} / \mathrm{L}$ dan COD akhir dengan penambahan konsentrasi mikroba 2.949,4 mg/L yaitu sebesar $65.66 \mathrm{mg} / \mathrm{L}$ dengan persentase penurunan $70.61 \%$.

Hasil yang didapat sedikit berbeda dengan penelitian lain yang mendapatkan nilai terbaik dalam 48 jam dengan persentase penurunan $83,93 \%(12)$. Serta terdapat pula yang mendapatkan nilai terbaik dalam 2 jam dengan persentase penurunan $86,35 \%{ }^{(13)}$. Hal tersebut dapat terjadi karena adanya perbedaan waktu penambahan mikroorganisme dalam setiap penelitian, yang secara langsung dapat berpengaruh juga terhadap kualitas air limbah ${ }^{(11)}$.

\subsection{Pengaruh Konsentrasi Mikroba Terhadap Penurunan BOD}

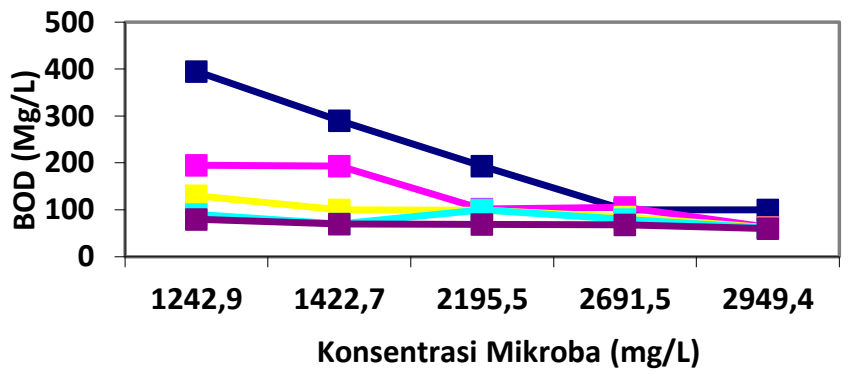

-2 Jam -3 Jam 4 Jam

Gambar 8. Hubungan konsentrasi mikroba dengan penurunan BOD

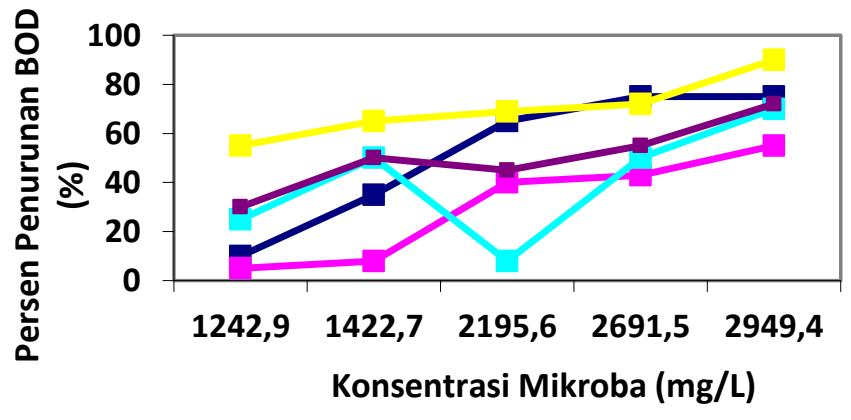

$\rightarrow 2$ Jam $\quad-3$ Jam -4 Jam

Gambar 9. Persentase penurunan BOD (\%) 
Gambar 8 dan 9 menunjukkan penurunan hasil BOD dengan penambahan konsentrasi mikroba pada proses aerasi. Dengan semakin besar waktu pengontakan aerasi serta dengan penambahan konsentrasi mikroba maka akan semakin besar proses pendegradasian bahan organik yang ada pada air limbah. Hal ini menyebabkan penurunan nilai $\mathrm{COD}$ dan $\mathrm{BOD}$ menjadi semakin besar. Pada proses ini didapatkan waktu terbaik yaitu 6 jam. Dengan nilai BOD awal sebesar 101,4 mg/L dan BOD akhir dengan penambahan konsentrasi mikroba $2.949,4 \mathrm{mg} / \mathrm{L}$ yaitu sebesar $30,26 \mathrm{mg} / \mathrm{L}$ dengan persentase penurunan sebesar $70,15 \%$.

Hal tersebut didukung dengan penelitian lain yang menyatakan bahwa penambahan mikroba juga berpengaruh secara efektif terhadap penurunan nilai BOD pada limbah tahu, dengan keefektifan penurunan masing-masing sebesar $55,43 \%$ untuk dosis $1 \mathrm{ml} / \mathrm{L}, 60,94 \%$ dosis $2 \mathrm{ml} / \mathrm{L}$, dan $67,41 \%$ pada dosis $3 \mathrm{ml} / \mathrm{L}^{(15)}$.

Terdapat pula penelitian yang menemukan bahwa meskipun sama-sama mengalami penurunan $\mathrm{BOD}$, tetapi waktu aerasi terbaik yang didapat yaitu dalam waktu 2 jam pada konsentrasi mikroorganisme $1.600 \mathrm{ml} / \mathrm{g}$ dengan penurunan BOD sebesar $83,99 \%(13)$. Hal tersebut dapat terjadi karena adanya perbedaan waktu penambahan mikroorganisme dalam setiap penelitian, yang secara langsung dapat berpengaruh juga terhadap kualitas air limbah(12,14).

\section{KESIMPULAN}

Limbah cair industri pakan ternak sebelum dilakukan proses memiliki karakteristik seperti berikut, COD 1.035,97 mg/L, BOD 937,63 mg/L, dan $\mathrm{pH} 7,58$. Pada proses aerasi selama 6 jam diperoleh kadar COD 223,46 mg/L dengan persentase penurunan $78,42 \%$ dan BOD akhir sebesar $101,4 \mathrm{mg} / \mathrm{L}$ dengan persentase penurunan $89,18 \%$.

Pada proses biologi aerob dengan penambahan konsentrasi mikroba 2.949,4 mg/L dan waktu proses selama 6 jam diperoleh kadar COD sebesar $65,66 \mathrm{mg} / \mathrm{L}$ dengan persentase penurunan $70,61 \%$ dan BOD sebesar $30,26 \mathrm{mg} / \mathrm{L}$ dengan persentase penurunan sebesar $70,15 \%$.

Berdasarkan hasil penelitian tersebut, proses aerasi saja nilai COD sebesar $223,46 \mathrm{mg} / \mathrm{L}$ dan BOD sebesar $101 \mathrm{mg} / \mathrm{L}$ masih belum memenuhi standar baku mutu limbah cair. Pada proses biologi aerob dihasilkan limbah cair dengan nilai COD sebesar $65,66 \mathrm{mg} / \mathrm{L}$ dan $\mathrm{BOD}$ sebesar $30,26 \mathrm{mg} / \mathrm{L}$. Proses pengolahan limbah cair industri pakan ternak dengan kombinasi proses aerasi dan biologi aerob dapat menghasilkan limbah cair yang sudah memenuhi standar baku mutu limbah cair.

\section{PERSANTUNAN}

Ucapan terima kasih kami sampaikan kepada Program Studi Teknik Kimia khususnya Laboratorium Riset yang telah memfasilitasi pelaksanaan penelitian ini.

\section{DAFTAR PUSTAKA}

1. Undang-Undang Republik Indonesia Nomor 32 Tahun 2009 Tentang Perlindungan dan Pengelolaan Lingkungan Hidup.

2. Keputusan Menteri Negara Lingkungan Hidup Nomor KEP-51/MENLH/10/1995 Tentang Baku Mutu Limbah Cair Bagi Kegiatan Industri.

3. Luluk, E. \& Suprihatin. (2009). Kombinasi Proses Aerasi, Adsorpsi, dan Filtrasi Pada Pengolahan Air Limbah Industri Perikanan. Envirotek Jurnal IImu Teknologi Lingkungan. 2(1): 79-83.

4. Ningtyas, R. (2015). Pengolahan Air Limbah dengan Proses Lumpur Aktif Pengolahan Air Limbah dengan Proses Lumpur Aktif, Edisi 1. Bandung: Institut Teknologi Bandung.

5. Suriadi. E. (2003). Transfer Oksigen dalam Proses Aerasi. Buletin Penelitian, Vol. XXV No. 1.

6. Kapri Batara, W. O., \& Badrus Zaman. (2017). Pengaruh Debit Udara Dan Waktu Aerasi Terhadap. Jurnal Teknik Lingkungan. 6(1).

7. Sari, F. R., Annissa, R., \& Tuhuloula, A. (2013). Perbandingan Limbah dan Lumpur Aktif Terhadap Pengaruh Sistem Aerasi Pada Pengolahan Limbah CPO. Jurnal Konversi UNLAM, 2(1): 40-45, doi: 10.20527/k.v2i1.128.

8. Hermanus, M. B., Polii, B., \& Mandey, L. C. (2015). Pengaruh Perlakuan Aerob dan Anaerob Terhadap Variabel BOD, COD, pH, dan Bakteri Dominan Limbah Industri Desiccated Coconut PT. Global Coconut Radey, Minahasa Selatan. IImu dan Teknologi Pangan, 3(2): 48-59.

9. Yuniarti, D. P., Komala, R., \& Aziz, S. (2019). Pengaruh Proses Aerasi Terhadap Pengolahan Limbah Cair Pabrik Kelapa Sawit Di PTPN VII Secara Aerobik. Jurnal Redoks, 4(2): 7-16.

10. Hidayah, E. N., Djalalembah, A., Asmar,G. A. \& Cahyonugroho, O. H., (2018). Pengaruh Aerasi Dalam Constructed Wetland Pada Pengolahan Air Limbah Domestik. Jurnal IImu Lingkungan. 16(2): 155, doi: 10.14710/jil.16.2.155-161.

11. Arsawan, M., Budiarsa Suyasa, I., \& 
Suarna,W. (2012). Pemanfaatan Metode Aerasi Dalam Pengolahan Limbah Berminyak. Ecotrophic Journal Environment Science. 2(2): 1-9.

12. Anggreni, W., Budiarsa Suyasa, I., \& Dwijani, W. S., (2014). Pengaruh Perlakuan Biofiltrasi Ekosistem Buatan Terhadap Penurunan COD, Nitrat, Dan Ph Air Limbah Pencucian Rumput Laut. Jurnal Kimia. 8(1): 97-103.

13. Utami, L. I., Wihandhita, W. S., Marsela, \& Nurma, K. (2017). Pengolahan Limbah Cair Minyak Bumi Secara Biologi Aerob Proses
Batch. Jurnal Teknik Kimia. 11(2): 37-41.

14. Eko, M. \& Romayanto, W., (2006). Pengolahan Limbah Domestik dengan Aerasi dan Penambahan Bakteri Pseudomonas putida. Bioteknologi. 3(2): 42-49, doi: 10.13057/biotek/c030202.

15. Rizky, K. A.. (2013). Pengaruh penambahan EM-4 (Effective Microorganisms-4) Terhadap Penurunan BOD (Biological Oxygen Demand) Limbah Cair Tahu. Universitas Muhammadiyah Surakarta. 